\title{
Exploring the Relationship Between Education and Tourism: A Case Study of Erasmus Students at the University of Economics - Varna
}

\author{
PhD candidate Katina Popova \\ University of Economics - Varna, Varna, Bulgaria \\ katina_popova@ue-varna.bg
}

\begin{abstract}
International travels motivated by participation in exchange programs, form a significant part of the dynamically developing market for tourist products and services. The combination of studying abroad with the choice of tourist destination is a common practice among students around the world. The aim of the current study is to establish the relationship between study abroad programs and tourism during the stay in the chosen destination, through a case study of Erasmus students at the University of Economics - Varna. For the purpose of the study a survey had been conducted among representatives of international Erasmus students in UE-Varna. The results showed that the relationship between education and tourism is more likely to intensify within and outside the country. In the context of follow-up studies, the results could be adapted to identify the potential economic contribution of the Erasmus programme to the tourism development in the destination.
\end{abstract}

Keywords: Erasmus, study abroad, tourism, University of Economics - Varna

JEL Code: Z320; doi:10.36997/IJUSV-ESS/2019.8.2.27

Въведение

Туризмът, практикуван по линия на участието в програми за научен обмен, е продукт на интернационализацията в образованието. Посевместното разпространение на информационно-комуникационните технологии разширява аудиторията на образователния туризъм, предлагайки все по-вече и все по-различни дестинации, в които ученето е неразривно свръзано с възможностите за оползотворяване на свободното време чрез участие в различни туристически дейности. Целта на настоящата публикация е да установи мащаба на взаимовръзката „образование - туризъм” чрез проучване на общата удовлетвореност и мотивите за предприемане на пътуване до дестинация България сред чуждестранните студенти по програма „Еразъм” в Икономически университет - Варна. Така формулираната цел се постига с изпълнението на следните изследователски задачи: установяване на спецификите на програма „Еразъм” в международен план; изследване на специализираната литература, посветена на образоватлния туризъм и извеждане на проучването чрез кейсметода; анализ на факторите, влияещи върху избора на дестинаџия сред студентите, както и оценка на степента на тяхната удовлетвореност след престоя им.

\section{1. Методология и преглед на литературата}

Специфична детерминанта на съвременния начин на живот е връзката между глобализацията и интернационализацията. Разглеждането на тези два термина като синоними следва да се приема с известна условност. Глобализацията е дефинирана като процес на непрекъснато нарастване на икономическите, социалните, техническите, политическите и културните връзки и отношения между отделните страни, общества и организации в световен мащаб (Русев, 2013). В този смисъл тя може да бъде разбирана като форма на международна интеграция. От своя страна, интернационализацията е сьвкупност от предприетите от институциите политики и практики за справяне с предизвикателствата на глобалната епоха (Monteiro et al., 2016). Едно от основните нейни измерения е разширяването на академичните перспективи и осигуряване на качествено международно образование (Терзиева, 2012). Интегрирането на мобилността в учебната програма е фактор за развитие на приобщаващата функция на висшето образование в световен, европейски и национален мащаб (де Вит и кол., 2015). Подобна форма на модернизация се реализира чрез 
програми за научен обмен, водеща роля от които има „Еразъм”. В качеството си на инструмент за имплементиране на нови идеи в обучението, програмата е създадена за подобряване на уменията и компетенциите на обучаващите се, с оглед осигуряването на всичкоквалифицирана работна сила (Gonzalez et al., 2011; Breznik et al., 2013). Тя има сериозен принос за увеличаването на мобилността във висшето образование на европейско равнище, а участниците в нея са наричани „посланици” на мултикултурализма и трансграничното сътрудничество (Breznik et al., 2013). От създаването си през 1987 г. повече от три милиона студенти получават субсидия, като тенденцията за нейното ежегодно увеличаване се запазва почти изцяло устойчива във времето (Monteiro et al., 2016). Международната мобилност дава тласьк на развитието на образователния туризъм, който най-общо може да бъде определен като специализирано пътуване, чиято основна цел получаване на обучение и удовлетворяване на индивидуални образователни потребности и мотиви в туристическо място, предлагащо продукти и услуги, разработени в съответствие с определена образователна програма (Казанджиева, 2018). С нарастването на мащабите на явлението, изследователите все по-често акцентират върху факта, че в много случаи водещият мотив за предприемане на образователно пътуване постепенно се изменя и в основата му стоят конкурентните предимства на дестинацията и индивидуалните перцепции за нея в съзнанието на туристите (Ritchie, 2013; Monteiro et al., 2014). Вземането на решение за участие в програма за научен обмен е неразривно свързано с имиджа на туристическото място, неговата естествена среда и предлагането на диверсифициран продукт (LlewellynSmith et al., 2008; García-Rodríguez et al., 2015).

Проучването е разработено според метода на примерния казус ${ }^{1}$. Неговите особености и предимства могат да бъдат обобщени по следния начин (Harling, 2002; Михайлов, 2014):

$\checkmark$ изучаваният феномен може да бъде различен по вид и големина - програма, събитие, дейност или проблем;

$\checkmark$ естествената среда е контекстьт, в който се появява и развива явлението изследваният проблем и контекстуалните условия са взаимно обвързани;

$\checkmark$ използването на холистичен подход при изследването създава възможност за увеличаване на обхвата на научната мисъл, чрез включване на различни източници за информация - наблюдение, дълбочинно интервю, анкети, доклади и други материали;

$\checkmark$ вариативността на проучването позволява промяна или комбиниране на резултатите за целите на последващи проучвания с друг ракурс.

За изследване на общата удовлетвореност от програма „Еразъм” и установяване на връзката „образование-туризъм” в периода февруари - юни 2019 г. бе проведено онлайн анкетно проучване сред студенти от Икономически университет - Варна - чуждестранни граждани, посетили дестинацията през последните няколко години. Чрез индуктивни умозаключения ${ }^{2}$ и по метода на генерализацията ${ }^{3}$ са направени изводи за мотивите за пьтуване, общата удовлетвореност и пост-програмните впечатления на представители на различни национални пазари. В допълнение, като метод на качественото проучване, в настоящата разработка е представена част от дълбочинно интервю, проведено с координатор

\footnotetext{
${ }^{1}$ Метод на примерния казус, метод на единичния (индивидуалния) случай, изследване на ситуация (англ. саsе study) (рус. кейс-метод; кейс-стади) - метод за изследване, основан на проучване на особеностите и сложностите на конкретен (единичен, определен) случай или феномен (Гусева, 2013). В структурно отношение се състои от подробно описание на явлението, характеристика на събитията, довели до неговото съществуване и проучване на неговите особености и проявления. Ако анализът на тези елементи е направен чрез съобщаване на факти, тогава казусът се разглежда като форма на описателния метод, но ако се пристъпи към причинноследствените връзки, тогава методът е причнно-екпериментален (Starman, 2013).

${ }^{2}$ Индуктивни умозаключения - заключение, в което връзката между предпоставките и умозаключението не се опира на логически закон. Предаване на характеристики от частния случай към общия (Гюров, 2014).

3 Генерализация - логическа техника, включваща обобщение и преход от конкретното към общото; подчиняване на определени явления на общия принцип (Баженова, 2015).
} 
по програма „Еразъм” в Икономически университет - Варна.

\section{2. Специфики на програма „Еразъм” и мястото на България в нея}

Мобилността по програма „Еразъм”, поставяща акцент върху развитието на активното гражданство и професионалните умения, е един от централните елементи на стратегиите на Европейската комисия. В социокултурно и икономическо отношение нейната роля се изразява по следния начин (ЕС, 2015):

- борба с младежката безработица - според проучванията рискът от дългосрочна безработица се намалява наполовина за мобилните студенти;

- усъвършенстване на личностните качества и способности - повишават се нивата на междукултурна осведоменост и се развиват т.нар. меки умения (бърза адаптация към промените, включване в разрешаването на проблеми, умения за работа в екип, толерантност към различни възгледи, мнения и позиции);

- професионално развитие - подобряват се чуждоезиковите умения и професионалните компетенции, което определя участниците в програмата като конкурентоспособна работна сила с безспорни предимства при кандидатстване за работа.

На 11.12.2013 г. с Регламент № 1288 на Европейския парламент е създадена „Еразъм+” - единна програма в областта на образованието, обучението, младежта и спорта, която обединява проекта „Обучение (учене) през целия живот” и други вече съществуващи програми, насочени към мобилността в образователната сфера, систематизирани в табл. 1 (ЕП, 2013). „Еразъм +” допринася за постигането на целите, заложени в стратегията „Европа 2020" и популяризирането на европейските ценности, съгласно Договора за Европейския съюз. Същностните характеристики и цели на програмата са (ЕC, 2017):

* признаване и валидиране на умения и квалификации чрез различни инструменти като Europass ${ }^{4}$, Youthpass $^{5}, \mathrm{EKP}^{6}, \mathrm{ECTS}^{7}, \mathrm{ECVET}^{8}, \mathrm{EQAVET}^{9}, \mathrm{EQAR}^{10}, \mathrm{ENQA}^{11}, \mathrm{NARIC}^{12}$;

* разпространение $u$ използване на резултатите от проектите, с цел усъвършенстване, обмяна на опит и адаптиране на резултатите към други дейности;

* изискване за свободен достъп до образователните материали, документи и аудиовизуални продукти, изготвени чрез програмата, за целите на широкообхватното приложение при учене, преподаване, работа с младежи и обучение на кадри;

* високи нива на международно присъствие, с цел сътрудничество с държави партньори в областите на висшето образование и младежта;

* многоезичие, символ на концепцията за глобалното гражданство и културното многообразие, имащо за цел повишаване на ефикасността и ефективността на програмата;

* равнопоставеност, приобщаване и защита, чрез улеснен достъп на участниците в неравностойно положение (с увреждания, образователни или икономически затруднения, социокултурни различия или затруднения поради географски причини като отдалеченост и

\footnotetext{
${ }^{4}$ Europass - набор от документи, служещи като паспорт за мобилност на европейците.

${ }^{5}$ Youthpass - сертификат, документиращ развитието на компетенциите и потвърждаващ участието в проекти.

${ }^{6}$ ЕКР - европейска квалификационна рамка.

${ }^{7}$ ECTS - European Credit Transfer and Accumulation System (Европейска система за трансфер и натрупване на кредити).

${ }^{8}$ ECVET - European Credit System for Vocational Education and Training (Европейска система за трансфер на кредити в професионалното образование и обучение).

${ }^{9}$ EQAVET - European Quality Assurance in Vocational Education and Training (Европейска референтна рамка за осигуряване на качество в професионалното образование и обучение).

${ }^{10}$ EQAR - European Quality Assurance Register for Higher Education (Европейски регистър за осигуряване на качество).

${ }^{11}$ ENQA - European Association for Quality Assurance in Higher Education (Европейска асоциация за осигуряване на качество във висшето образование).

12 NARIC - National Academic Recognition Information Centre (Nационални информационни центрове за академично признаване).
} 
откъснатост от развитите райони).

Таблица 1. Програмно съдържание на „Еразъм +”

\begin{tabular}{|c|c|c|}
\hline \multicolumn{3}{|r|}{ Съдържание на програма „Еразъм +” } \\
\hline № & Програми & Кратка характеристика \\
\hline 1 & $\begin{array}{c}\text { Учене през } \\
\text { иелия живот }\end{array}$ & $\begin{array}{l}\text { Всички образователни и обучителни инициативи на Европейската комисия се } \\
\text { обединяват под шапката на концепцията „Учене през целия живот” (англ. } \\
\text { LLL - Lifelong Learning). }\end{array}$ \\
\hline 1.1 & Еразьм & $\begin{array}{l}\text { Създадена през } 1987 \text { г. По-късно е включена към концепцията „Учене през } \\
\text { целия живот”, част от съдъжателната характеристика на стартиралата през } \\
2014 \text { г. програма „Еразъм +”. Наименованието ѝ произхожда от името на } \\
\text { холандския философ, богослов и ренесансов хуманист Дезидерий Еразъм от } \\
\text { Ротердам, създател на центъра на европейския интелектуален живот по време } \\
\text { на Възраждането. }\end{array}$ \\
\hline 1.2 & $\begin{array}{l}\text { Леонардо да } \\
\text { Винчи }\end{array}$ & $\begin{array}{l}\text { Създадена през } 1995 \text { г. Акцентира върху професионалното образование и } \\
\text { обучени. Цели създаването на професионална мобилна работна ръка в } \\
\text { Европа. Основана на принципите на партньорството и иновациите. }\end{array}$ \\
\hline 1.3 & Коменски & $\begin{array}{l}\text { Създадена през } 1995 \text { г. Ориентирана към работа с младежите, с цел } \\
\text { опознаване на културното многообразие и усвояване на езици и европейски } \\
\text { ценности. }\end{array}$ \\
\hline 1.4 & Грюндвиг & $\begin{array}{l}\text { Създадена през } 2000 \text { г. Насочена към всички възрасти. Цели повишаване на } \\
\text { знания и компетенции, чрез участие в индивидуални или групов проекти и } \\
\text { обучаване на групи, отпаднали от образователната система. }\end{array}$ \\
\hline 1.5 & Учебни визити & $\begin{array}{l}\text { Създадена през } 2008 \text { г. Цели насьрчаване и подкрепа на политическото } \\
\text { развитие и сьтрудничество на общоевропейско ниво в контекста на ученето } \\
\text { през целия живот. }\end{array}$ \\
\hline 2 & $\begin{array}{l}\text { Младежта в } \\
\text { действие }\end{array}$ & $\begin{array}{lccccccc}\text { Създадена през } 2008 \text { г. Главната ѝ цел е развитие на } & \text { младежкото } \\
\text { сътрудничеството в EC, чрез групови обмени и доброволчество. } & \\
\end{array}$ \\
\hline 3 & Еразмус Мундус & $\begin{array}{l}\text { Създадена през } 2009 \text { г. Им за цел да повиши качеството на европейското } \\
\text { висше образование и да насьрчи диалога между хората и културите чрез } \\
\text { сътрудничество с трети страни. }\end{array}$ \\
\hline 4 & Темпус & $\begin{array}{l}\text { Създадена през } 2008 \text { г. Подпомага модернизирането на висшето образование } \\
\text { в държави партньори, намиращи се в географска близост до ЕС. }\end{array}$ \\
\hline 5 & Алфа & $\begin{array}{l}\text { Създадена през } 1994 \text { г. Насърчава сътрудничеството между Латинска } \\
\text { Америка и Европа в областта на висшето образование, с цел обмен на знания } \\
\text { и ноу-хау за подобряване на академичния, научния и технологичния } \\
\text { потенциал на латиноамериканските държави. }\end{array}$ \\
\hline 6 & Едулинк & $\begin{array}{l}\text { Създадена през } 2006 \text { г. Насърчава интеграцията във висшето образование чрез } \\
\text { изграждане на институционални мрежи. Цели постигането на качеств, } \\
\text { ефикасност на образователната система, във връзка с ролята ѝ на пазара на } \\
\text { труда, приоритетно в Африка, Карибите и Тихоокеанския басейн. }\end{array}$ \\
\hline 7 & $\begin{array}{l}\text { Двустранно } \\
\text { сътрудничество }\end{array}$ & $\begin{array}{l}\text { Създадена през } 2002 \text { г. Включва проекти за регионално сътрудничество, } \\
\text { основаващи се на съвместно финансиране от трети държави, в контекста на } \\
\text { създаване на стратегически партньорства в областта на висшето образование. }\end{array}$ \\
\hline 8 & Жан Моне & $\begin{array}{l}\text { Създадена през } 2010 \text { г. В контекста на европейските ценности, представлява } \\
\text { кратки учебни програми или курсове по въпросите на ЕС. }\end{array}$ \\
\hline 9 & Cnopm & $\begin{array}{l}\text { Създадена през } 2010 \text { г. Цели мобилност на млади атлети и създаване на } \\
\text { възможности за тренировки в чуждестранни клубове. }\end{array}$ \\
\hline
\end{tabular}

Източник: информацията в таблицата е систематизиранаот автора по материали на www.es.europa.eu и www.old.hrdc.bg

Включването на България в програмата е едно от най-големите предимства за българското академично образование. Тя не само създава възможности за по-добра реализация на участниците, но е и двигател на мултикултурните процеси, протичащи в 
страната (Попова, 2018). Според изследванията 50\% от българските работодатели са склонни да изплащат по-високи трудови възнаграждения на новонаети служители, ако те са носители на подобен задграничен опит, а $90 \%$ от участниците в програмата декларират високо и осъзнато самочувствие на равноправни европейски граждани (Brandemburg et. al, 2016).

\section{3. Изследване на взаимовръзката „образование - туризъм” сред международните} студенти по програма „Еразъм” в Икономически университет - Варна

По данни на отдел „Международно сътрудничество” в Икономически университет Варна, за последните няколко академични години, броят на входящите студенти по програмата варира както следва: 2011/2012 - 43 души; 2012/2013 - 36 души; 2013/2014 - 42 души; 2014/2015 - 45 души; 2015/2016 - 50 души; 2016/2017 - 46 души; 2017/2018 - 67 души; 2018/2019 - 72 души. Статистиката ясно показва прогресивния растеж на международното студентско присъствие в конкретния университет след 2015 г. Институцията има подписани договори за сътрудничество и обмен със 175 висши учебни заведения в и извън ЕС. Във времево отношение преобладават престоите в рамките на един семестьр, а едногодишните (двусеместриалните) формират едва 3\% от общия брой на реализираните в ИУ-Варна обмени. В анкетното проучване се включиха общо 90 чуждестранни студенти, от които 51\% са посетили Варна по линия на програмата през учебната 2017-2018 г., 47\% - през изминалата 2018-2019 г., а останалите 2\% са реализирали обмена си в периода 2013-2014 г. Техният престой потвърждава общата статистика, предоставена от отдел „Международно сьтрудничество" - 91\% от анкетираните са пребивавали на територията на университета в рамките на един учебен семестьр (3-6 месеца). Респондентите са представители на различни националности и социално-икономически групи (вж. фиг. 1, 2, 3 и 4).

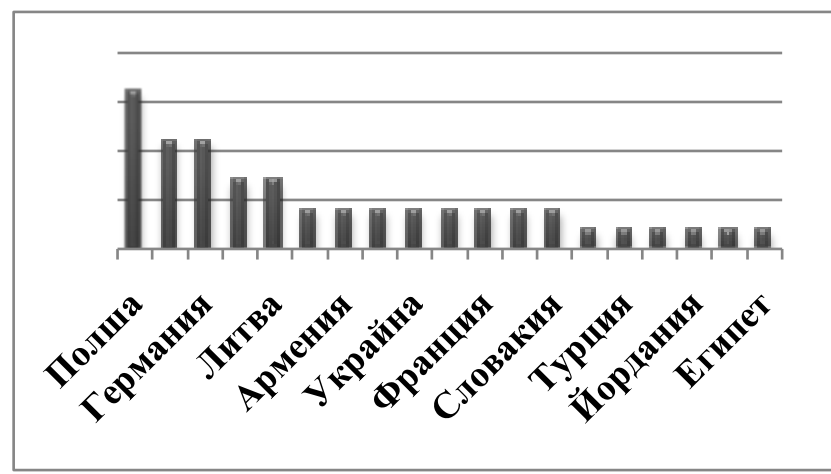

Източник: фигурата е съставена от автора Фиг.1. Националност на респондентите

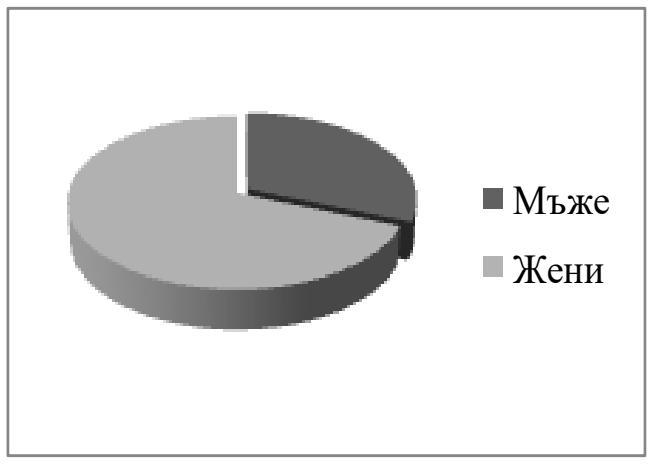

Източник: фигурата е съставена от автора Фиг.2. Пол на респондентите

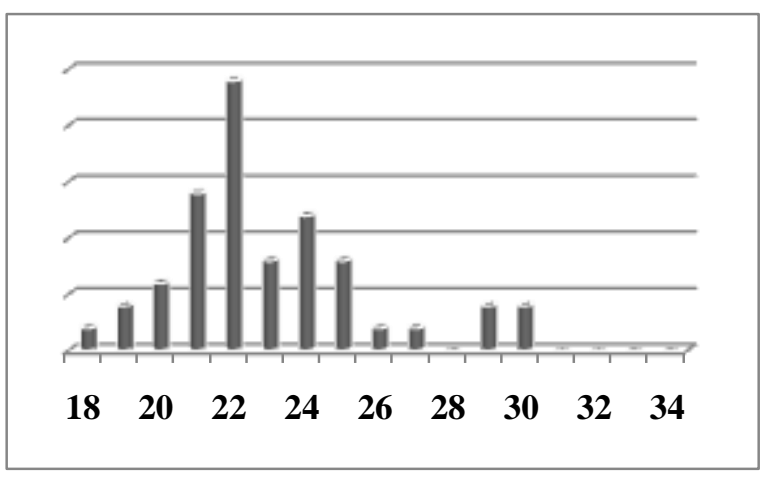

Източник: фигурата е съставена от автора Фиг.2. Възраст на респондентите

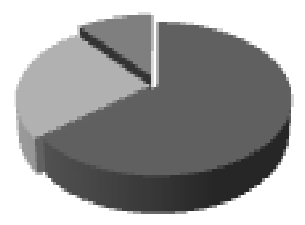

По-нисък средния за страната

- Среден за страната

Източник: фигурата е съставена от автора Фиг.4. Среден семеен доход 
Преобладава присъствието на представители на европейски държави. Най-много са респондентите от Полша, следвани от Италия, Германия, Чешка република и Литва. Във възрастово отношение преобладават лицата между 22 г. и 24 г., а в полово - превес имат жените (69\%). Повече от 70\% от участниците в проучването декларират семеен доход на средни за своята държава нива. Над $78 \%$ от чуждестранните студенти (в своите страни по местожителство) следват икономически специалности (финанси, международен икономикс, счетоводство и др), близо 9\% - социални науки (социология, география, туризъм) и почти толкова - математико-инженерни специалности като строителство, програмиране и др. 71\% от участвалите в програмата се обучават в ОКС „бакалавър”. Мотивите за участие в програма „Еразъм” се крият в желанието за: подобряване на езиковите умения и опит за научаване на нов език (80\%); обогатяване на академичната биография (54\%); създаване на приятелства и контакти (63\%), следвани от възможностите за опознаване на чужди култури и традиции и следване на примера на приятели и/или роднини.

Както вече посочихме, все по-често срещано явление е образователната дестинация да бъде избирана не само заради качеството на академичния продукт, но и заради възможностите за практикуване на различни дейности, които тя предоставя. 53\% от респондентите признават, че България е била техният първоначален избор при стартиране на участието в програмата. Предвид младежката им възраст и често обусловяните от нея финансови и дори социални затруднения, ролята на семейството е изключително важна за личностното и академичното развитие на студентите. Имиджът и позиционирането на дестинация България на международния образователен и туристически пазар могат да бъдат оценени и според мнението на най-близките: $62 \%$ от участниците са били морално и финансово подкрепени от своите семейства, а 29\% - само морално. Едва 2\% признават, че пътуването им изобщо не е било ситмулирано, а 7\% са били посъветвани да изберат друга дестинация. Основните причини, поради които дестинация Варна и Икономически университет са реалният избор на респондентите, са особено важни за индентифициране на качеството и привлекателнстта на предлагания продукт (вж. фиг. 5 и 6).

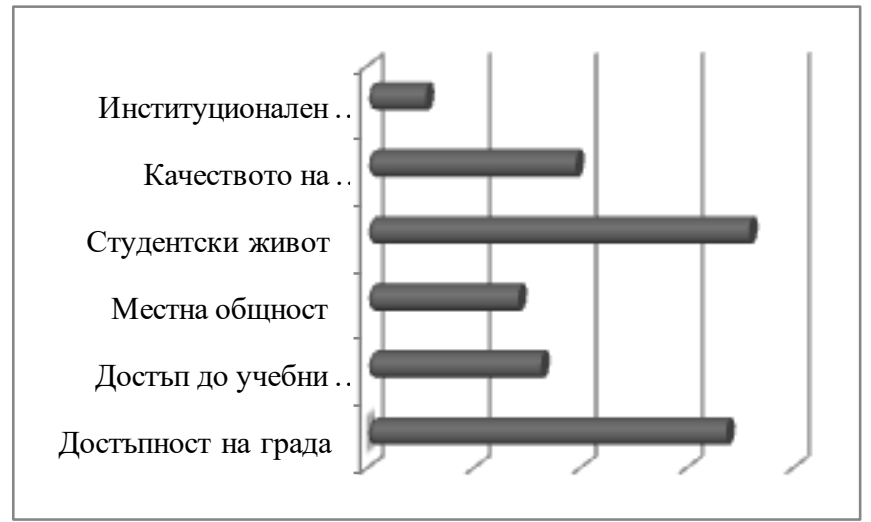

Източник: фигурата е съставена от автора

Фиг.5. Фактори за избор на образователна институция

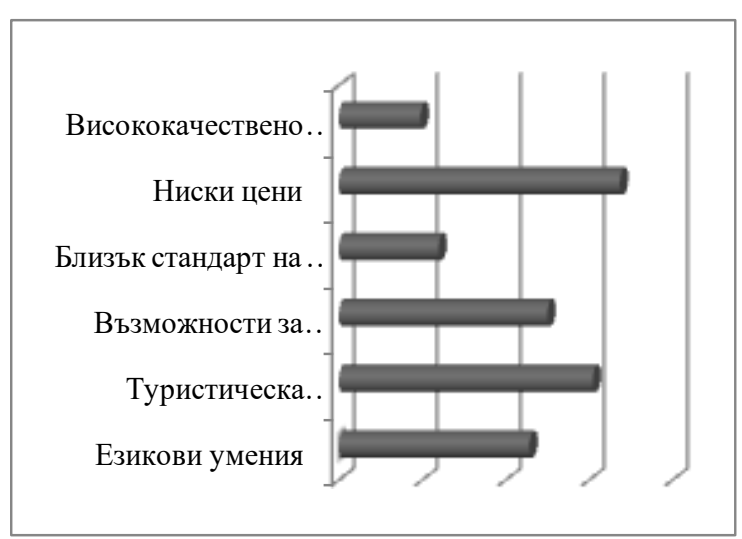

Източник: фигурата е съставена от автора Фиг.6. Фактори за избор на образователна дестинация

Икономически университет - Варна е предпочетен заради стратегическото си местоположение в град, който създава възможност за разнообразен и изпълнен с емоции студентски живот $(71,7 \%)$ и разполага с добра обезпеченост от гледна точка на транспорт, места за пребиваване, медицински и финансови институции $(67,4 \%)$. Що се отнася до предлагания образователен продукт, над 39\% от респондентите признават, че техният избор е продиктуван от качеството на преподавателските умения, улеснения достьп до учебни материали $(32,6 \%)$ и институционалния престиж на учебното заведение $(10,9 \%)$. Несъмнено, 
всички тези предимства са допълнени и от усещането за спокойствие, създавано от гостоприемството на местното население в дестинацията (28,3\%). Предпочитанията към град Варна се крият най-вече в ниските цени на продукти и услуги $(67,4 \%)$ и облика му като туристическа дестинация $(60,9 \%)$. Важни за избора на чуждестранните студенти са и възможността за участие в различни младежки дейности $(50 \%)$ и сравнително лесното постигане на пълноценен диалог с останалите, благодарение на езиковите умения на местната общност и академичния персонал (45,7\%). Като допълнителни фактори могат да бъдат посочени близкият стандарт на живот до този в националната държава на студента $(23,9 \%)$ и високото ниво на качеството на образование, предоставяно в града $(19,6 \%)$.

По време на престоя си в рамките на програмата $53 \%$ от участиците в проучването са били настанени в студентски общежития, 42\% - в частни квартири, а 5\% - в младежки хостели. Туризмът и общуването с културата на българите е неизменна част от пребиваването на всеки един от тях. Превес на посещенията бележат обектите на материалното и нематериалното културно наследство, носещи белезите на историята, народопсихологията и бита на местното население - съответно с по 67,4\% и 58,7\% дял на отговорите. Атрактивността на природните ресурси също остава висока $(67,4 \%)$, следвана от интереса към религиозните обекти $(34,8 \%)$ и участието в спортни и/или приключенски туристически дейности $(17,4 \%)$. Малък процент от участниците в проучването признават, че не са практикували подобни активности $(4,3 \%)$. В своите обиколки респондентите са посетили не само града $(13 \%)$, но и обекти от цялата страна $(19,6 \%)$. Повечето от тях са успели да направят визита и на съседни на България държави $(67,4 \%)$. В по-голямата част от случаите туристическите пътувания са организирани по собствена инициатива - идея на самите студенти и техните колеги и/или приятели (89,2\%). Сравнително по-малък процент са мотивирани от други инициатори като местна младежка или студентска организация $(6,5 \%)$ и посрещащата академична институция (4,3\%). Участието в подобни неформални мероприятия позволява оценка на дестинацията според критерия ,атрактивност”. Малко над 50\% от респондентите поставят развитието й някъде в средните нива, поради необходимостта от различни подобрения на предлагането, а 48,9\% го оценяват като отлично, изтъквайки изобилието от ресурси, които посрещат нуждите на младежите.

На световната и европейска икономическа сцена България е известна като дестинация на „евтин” туристически продукт. Оценката на съотношението „цена-качество” в конкретното проучване е получена не само от гледна точка на туристическото предлагане, но и по отношение на елементите на образователния продукт, както следва: отлично (37,8\%); много добро (24,4\%); добро $(28,9 \%)$; средно $(8,9 \%)$; ниско $(0 \%)$. Всичко това отново потвърждава тезата, че Варна и Икономически университет са пресечна точка между образованието като необходимост и туризма като начин за опознаване на чуждите култури.

\section{4. Изводи и препоръки}

Ресурсите, които оказват влияние върху избора на дестинация за научен обмен могат да бъдат обобщени в следните групи:

○ идеографска стойност на дестинацията - стратегическо местоположение, наличие на образователни и туристически ресурси, инфраструктура и суперструктура;

○ познавателна стойност на дестинацията - атрактивност, самобитност, индивидуалност, добавена стойност;

○ перцептивна стойност на дестинацията - степен на възприемане на ресурсите, индивидуално разбиране за съотношението „цена - качество”, социално значение на факторите, свързани с езиковите умения и гостоприемството на местното население.

Удовлетвореността от престоя по време на програмата в Икономически университет Варна е фактор за повишаване на интереса към дестинацията (вж. табл. 2). 
Таблица 2. Удовлетвореност от програмата и интерес към дестинацията

\begin{tabular}{|c|c|c|c|}
\hline $\begin{array}{l}\text { Интересувахте ли се } \\
\text { от България преди } \\
\text { посещението? }\end{array}$ & $\begin{array}{c}\text { Доколко сте удовлетворени от } \\
\text { програмата и престоя си в } \\
\text { България и Икономически } \\
\text { университет - Варна? }\end{array}$ & $\begin{array}{c}\text { Повиши ли се } \\
\text { интересът Ви към } \\
\text { България след } \\
\text { посещението? }\end{array}$ & $\begin{array}{c}\text { Каква е склонността } \\
\text { Ви към завръщане в } \\
\text { дестинацията? }\end{array}$ \\
\hline Да $(35,6 \%$ & Напълно удовлетворен $(55,6 \%)$ & $\begin{array}{c}\text { Определено да } \\
(64,4 \%)\end{array}$ & $\begin{array}{c}\text { Никога няма да се } \\
\text { върна отново }(6,7 \%)\end{array}$ \\
\hline \multirow[t]{3}{*}{ He $(64,4 \%)$} & Удовлетворен $(31,1 \%)$ & По-скоро да $(22,2 \%)$ & $\begin{array}{c}\text { Бих се върнал отново } \\
(20 \%)\end{array}$ \\
\hline & $\begin{array}{c}\text { Нито удовлетворен, нито } \\
\text { неудовлетворен }(13,3 \%)\end{array}$ & По-скоро не $(13,4 \%)$ & $\begin{array}{c}\text { Бих препорьчал } \\
\text { дестинацията на други } \\
\text { млади хора }(44,4 \%)\end{array}$ \\
\hline & Неудовлетворен (0\%) & Определено не (0\%) & $\begin{array}{c}\text { Бих се върнал с } \\
\text { приятели }(28,9 \%)\end{array}$ \\
\hline
\end{tabular}

Източник: информацията в таблицата е систематизирана и обобщена от автора

След края на програмата чуждестранните студенти посочват следните ползи от участието си: среща с нови хора, увеличаване на социалните контакти и създаване на нови приятелства $(67,4 \%)$; натрупване на опит чрез пътуването $(65,2 \%)$; осъзнаване и възприемане на култури, традиции и начини на мислене, различни от собствените $(41,3 \%)$; обогатяване на личната биография (37\%); повишаване на конкурентоспособността на студента на трудовия пазар (26,1\%); изграждане на умения и способности за лична грижа $(26,1 \%)$; усвояване на принципите на екипната работа $(15,2 \%)$. Конкретните пост-програмни впечатления водят до висока потребителска удовлетвореност от престоя, повишаване на интереса към дестинацията и склонността към завръщане в нея.

Възприемането на България и в частност - Варна като дестинация, подходяща за почти всички форми на младежки изяви, несъмнено се дължи на високото качествено равнище на Икономически университет - Варна и неговия академичен персонал. Взаимовръзката между образованието и туризма при престоя на младите може да бъде доусъвършенствана чрез нови инициативи и дейности, предложени от посрещащата институция. Така например, за своите международи студенти университетът организира еднодневна екскурзия до близките околности - Аладжа манастир и нос Калиакра. Във връзка с по-бързото приспособяване на младежите към местните условия в университета е въведена т.нар. „адаптационна седмица”, предхождаща началото на всеки семестър. Тя се състои от две части. Пьрвата преминава под мотото "Welcome days" - в рамките на три дни се изнасят лекции и семинари, свързани със запознаването на студентите с ИУ - Варна, града и страната като цяло. Важно място тук заемат т.нар. „българска вечер”, посветена на страната и нейните културни традиции. Младите чужденци имат възможността да тестват ястия от българската национална кухня, а на последния трети ден се организира специална викторина относно предварителните им общи познания за България. Като допълнителна атракция се предлага и включването на фолклорният ансамбъл на Икономически университет - „Гергана”, които приветстват новодошлите и включват в програмата си желаещите да изучават български народни танци. Втората част от адаптационната седмица предлага възможността да бъдат посетени различни лекции по предлаганите дисциплини и да се изберат курсове, които наймного се доближават до изискванията и целите на пребиваването на студентите. Специална роля в академичния живот на участниците по програма „Еразъм” има "Buddy” - програмата, която предполага да бъдат избрани ментори на чужденците сред българските студенти, участвали в програмата. Ежемесечно се провеждат и тематични вечери, посветени на културата на различни страни и региони в Европа. На особен успех се радват и организираните кулинарни вечери, на които студентите получават възможността да участват в приготвянето, презентирането и дегустацията на различни национални специалитети и 
блюда. Във връзка с практикуването на туристически дейности, университетът предлага информация за организираните екскурзии на ESN България ${ }^{13}$.

Бъдещите дейности, върху които академичната общност следва да насочи усилия, се свързват най-вече с увеличаването на броя на организираните по инситутционална инициатива мероприятия (културни, туристически, социални и развлекателни) за чуждестранни студенти. Обогатяването на научните ресурси, повишаването на достьпа да учебна литература и личното отношение стоят в основата на подобряване на академичния престиж на учебното заведение, а оттам - и на атрактивността на град Варна като ориентирана към младите образователна дестинация. В стратегически аспект, намесата на публичния и частния сектор в подобряване на качеството на туристическите услуги при задържане на сравнително ниски ценови равнища би довела до извеждане на страната като пресечна точка на мултикултурализма, младежките движения и туристическите потоци.

\section{Заключение}

Настоящото изследване показва, че взаимовръзката между образованието и туризма като обективни необходимости на младите хора вероятно тепърва ще се засилва в рамките на и извън страната. Конкурентоспособните предимства на Икономически университет - Варна се дължат на качествата на учебния процес и компетентността на академичния персонал. Към това следва да се прибавят и даденостите на дестинацията - достьпност, ресурсна обезпеченост, международен имидж и ориентираност към нуждите на младежите. За целите на последващи проучвания, резултатите могат да бъдат адаптирани и приспособени към изучаване на евентуалния икономическия принос на програма „Еразъм” към развитието на туризма в дестинацията по отношение на основни и допълнителни туристически услуги, а в контекста на академизма - към генерализиране на препоръки за подобряване качеството на определени елементи на образователния продукт.

\section{References}

1. Bazhenova, Yu. (2015). K voprosu o generalizatsii kak metodu poznaniya ponyatiya kommunikativnoy kulyturay v pedagogicheskoy nauke. V: Teoriya i praktika obshtestvennogo razvitiya, 1(3), s. 181-183.

2. Guseva, O. (2013). Keys-stadi kak metod issledovaniya. Sankt Peterburg: Vaysshaya shkola ekonomiki, s. 2. [Online]. Available from: https://bit.ly/2m4Klut [Accessed 07/09/2019].

3. Gyurov, R. (2014). Logicheski osnovi na analiza: preobrazuvaniya i metodi. Sofiya: Studia Analitica, $11 \mathrm{~s}$.

4. de Vit i kol. (2015). Internatsionalizatsiya na vissheto obrazovanie. V: Prouchvane na Generalna direktsiya za vatreshni politiki kam Evropeyski parlament. Tematichen otdel B: Strukturni politiki i politiki na sblizhavane. Bryuksel: Generalna diserktsiya za vatreshni politiki, s. 3-6. [Online]. Available from: https://bit.ly/328xYH8 [Accessed 30/08/2019].

5. Kazandzhieva, V. (2018). Tendentsii v razvitieto na obrazovatelniya turizam. V: Izvestiya na Sayuza na uchenite, Seriya Ikonomicheski nauki, 7(1), s. 47-55.

6. Mihaylov, A. (2014). Keys-stadi - issledovatelyskaya strategiya ili meta-metod? V: "Ekonomika i sotsium, 3(12), s. 543-551.

7. Popova, K. (2018). Mladezhkiyat turizam - faktor za globalizirane na obrazovatelnata sreda v Balgariya. V: Izvestiya na Sayuza na uchenite, Seriya Ikonomicheski nauki, 7(1), s. 135-144.

\footnotetext{
${ }^{13}$ Erasmus Student Network (ESN) - България е неправителствена организация на доброволни начала, част от европейската студентска мрежа - Erasmus Student Network, формирана а през 2008 г. ESN организира многобройни събития, както за българските студенти, заминаващи на обмени в чужбина, така и за пребиваващите в България чуждестранни студенти. Има единадесет локални секции, работещи в сътрудничество с университети. Предоставя възможност на техните чуждестранни студенти да се запознаят с България и традициите ѝ, да намерят своето място в една мултикултурна среда (https://esnbg.org).
} 
8. Rusev, I. (2013). Shto e globalizatsiya? V: Globalizatsiya. Kratak elektronen uchebnik i bibliografiya. Varna: Steno, s. 1-17.

9. Terzieva, S. (2012). Internatsionalizatsiya i kachestvo na vissheto obrazovanie. V: Razvitie na vissheto obrazovanie. Sofiya: Tsentar za razvitie na choveshkite resursi. Natsionalna grupa Bolonski savetnitsi, s. 13-24.

10. Evropeyski parlament. (2013). Reglament (es) № 1288/2013 na Evropeyskiya parlament i na Saveta ot 11 dekemvri 2013 godina za sazdavane na „Erazam +““. [Online]. Available from: https://bit.ly/2kxoHrO [Accessed 07/09/2019].

11. Komisiya na Evropa. (2017). Erazam+: Rakovodstvo na programata. [Online]. Available from: https://bit.ly/2k5cNoW [Accessed 07/09/2019].

12. Brandenburg, U. et al. (2016). The Erasmus Impact Study: Regional Analysis. A Comparative Analysis of the Effects of Erasmus on the Personality, Skills and Careers of students in European regions and Selected Countries. Luxembourg: Publications Office of the EU.

13. Breznik, Kr. et al. (2013). On the Erasmus student mobility for studies. In: Active Citizenship by Knowledge, Management and Innovation. Zadar: International Conference "Management, Knowledge and Learning", pp. 1371-1377.

14. García-Rodríguez, F., J. Jiménez. (2015). The role of tourist destination in international students' choice of academic center: the case of erasmus programme in the Canary Islands. In: PASOS. Revista de Turismo y Patrimonio Cultural, 13(1), pp. 175-189.

15. Gonzalez, S., R. Mesanza, P. Mariel. (2011). The determinants of international student mobility flows: an empirical study on the Erasmus programme. In: Higher Education, 62(4), pp. 413430.

16. Harling, K. (2002). An Overview of Case Study. In: Case Studies: Their Future Role in Agricultural and Resource Economics. California: Annual meeting of the American Agricultural Economics Association, pp. 1-7.

17. Llewellyn-Smith, C., V. McCabe. (2008). What is the attraction for exchange students: The host destination or host university? Empirical evidence from a study of an Australian University. In: International Journal of Tourism Research, 10(6), pp. 593-607.

18. Monteiro, A., A. Pereira. (2016). Erasmus student travel motivations: a factor-cluster segmentation approach. In: Turísmo: Estudias y Prácticas, 5(1), pp. 7-39.

19. Monteiro, A., M. Gomes. (2014). A mobilidade académica europeia e o turismo educativo e cultural: Fatores de decisão e de motivação. In: Tourism and Hospitality International Journal, 2(1), pp. 154-173.

20. Ritchie, B. (2003). Managing Educational Tourism. Ontario: Channel View Publications.

21. Starman, A. (2013). The case study as a type of qualitative research. In: journal of contemporary educational studies, $1(1)$, pp. 28-43.

22. European Commission. (2015). Erasmus Facts, Figures \& Trends: The European Union support for student and staff exchanges and university cooperation in 2013-2014. Brussels: DirectorateGeneral for Education and Culture, $40 \mathrm{p}$.

23. https://ec.europa.eu

24. https://esnbg.org

25. http://old.hrdc.bg 